\title{
Coagulase Gene Typing with Emphasis on Methicillin-Resistance Staphylococci: Emergence to Public Health
}

\author{
Dalia A. Hamza1 ${ }^{*}$, Sohad M. Dorgham², Amany Arafa² \\ ${ }^{1}$ Department of Zoonoses, Faculty of Veterinary Medicine, Cairo University, Egypt \\ ${ }^{2}$ Department of Microbiology, National Research Center, Dokki, Giza, Egypt \\ Email:"daliahamza@cu.edu.eg,sohad_dorgham@yahoo.com,dr.amanyahmed@yahoo.com
}

Received 22 October 2015; accepted 22 December 2015; published 25 December 2015

Copyright (C) 2015 by authors and Scientific Research Publishing Inc.

This work is licensed under the Creative Commons Attribution International License (CC BY). http://creativecommons.org/licenses/by/4.0/

CC) (i) Open Access

\begin{abstract}
Emerging antimicrobial resistance among CNS is a concern in veterinary and human medicine. Coagulase test is considered as the key test to differentiate staphylococci to two groups, coagulase positive staphylococci (CPS) and coagulase negative staphylococci (CNS). A total of 200 Staphylococci strains were isolated with percentage $66.7 \%(200 / 300)$ from quarter milk samples. The total of $S$. aureus strains are 70 with percentage 35\% (70/200). Among 70 strains of $S$. aureus, 30 strains are coagulase positive $S$. aureus with percentage $43 \%(30 / 70)$ and coagulase negative $S$. aureus $57 \%(40 / 70)$. CNS other than $S$. aureus was detected with percentage $65 \%(130 / 200)$ from subclinical mastitic cows. We examine sixty isolates of staphylococci recovered from subclinical mastitis in dairy cattle which divided as ten isolates of coagulase positive $S$. aureus (CP S. aureus), ten isolates of coagulase negative $S$. aureus ( $\mathrm{CN} S$. aureus) and forty isolates of coagulase negative staphylococci (CNS) which identified using API-Staph Kits as S. chromogenes, S. simulans, S. haemolyticus, $S$. epidermidis and $S$. cohnii. The genotypic detection of coa gene and mecA gene was screened in CP S. aureus, CN S. aureus and CNS.
\end{abstract}

\section{Keywords}

Coagulase, coa Gene, mecA Gene, Staphylococci, Methicillin

\section{Introduction}

Staphylo-coagulase is an extracellular protein that has traditionally been used to differentiate S. aureus from the

"Corresponding author.

How to cite this paper: Hamza, D.A., Dorgham, S.M. and Arafa, A. (2015) Coagulase Gene Typing with Emphasis on Methicillin-Resistance Staphylococci: Emergence to Public Health. Advances in Infectious Diseases, 5, 196-203. 
less virulent staphylococci. S. aureus secretes two clotting factors, coagulase (Coa) and von Willebrand factor binding protein (vWbp). The Coa and vWbp together are required for the formation of abscesses and promote the non-proteolytic activation of prothrombin and cleavage of fibrinogen, reactions that are inhibited with specific antibody against each of these molecules. Coa and vWbp specific antibodies confer protection against abscess formation and S. aureus lethal bacteraemia [1]. Although Coa enzyme is also produced by Staphylococcus intermedius and some Staphylococcus hyicus strains but coagulase production is one of the most reliable criteria for the identification of $S$. aureus [2].

Coagulase-negative staphylococci (CNS), have become the most commonly isolated microorganisms from bovine milk in many countries and are regarded as emerging mastitis pathogens [3]. In addition, CNS are abundantly present both in the cows' environment [4] and on their teat apices [5]. Also CNS showed high virulence by their ability to form biofilm which also get cells in biofilm more resist to antimicrobial [6]. So we are focusing in this study on subclinical mastitic cows and we examine all recovered coagulase positive and coagulase negative staphylococci.

The resistance to methicillin is caused by the presence of the mecA gene, which encodes the 78-kDa penicillin-binding protein (PBP) 2a (or PBP2') [7]. Staphylococcus strains with mecA are resistant to lactam antibiotics and frequently code for multi-drug resistance, which may represent a serious health and economic concern [8]. Consequently, it is highly important to detect mecA, especially in all Staphylococcus strains [9].

The resistance genes might in some instances transfer from staphylococci of animal origin to staphylococci that cause infections in humans, thereby compromising antimicrobial treatment [10]. CNS colonising the udder of buffaloes and cows may represent a reservoir of different antibiotic resistance genes and SCCmec elements. This raised the question of whether the genetic background could be a reservoir for interspecies gene transfer among CNS and S. aureus in the udder as it was previously suggested in the intestinal tract [11].

In recent years, increasing numbers of reports have shown that the mecA gene is present in CNS strains, including hospital-acquired infections, neighborhoods [12], animal epidermis [9] [13], beaches [14] and public transportation systems [15].

Therefore, the present work aimed to: 1) detect the presence of coa gene in Staphylococci field isolates from subclinical mastitic cows phenotypically and genotypically; 2) detect methicillin resistance gene in $S$. aureus and other CNS.

\section{Materials and Methods}

\subsection{Sampling}

The study took place in private dairy farms surrounding Giza, Egypt. A total of 300 quarter milk samples milk samples were aseptically collected from 85 mastitic dairy cattle. The animals had not been treated with an antibiotic for at least 30 days prior to collection. Milk sample collection was performed using the method of the National Mastitis Council, with some modifications, under aseptic conditions [16].

\subsection{Isolation and Identification}

Each milk sample was plated on two plates the first plate containing Columbia Agar base with 5\% defibrinated sheep blood (Oxoid) and the second plate was mannitol salt agar. Test plates were incubated for $24-48$ hours at $37^{\circ} \mathrm{C} \pm 1^{\circ} \mathrm{C}$. All isolates were presumptively identified as staphylocooci based on colony morphology, Gram staining, catalase reaction, and oxidative-fermentative testing. After confirmation of the genus Staphylococcus, the enzyme coagulase was characterized among all isolates using both the slide and tube methods according to Quinn et al. [17]. Coagulase-negative isolates resistant to methicillin were subjected to identification to the species level using the API-Staph Kit (BioMerieux, P.O. Box 4328, Honeydew, 2040) as described by Petzer et al. [18].

\subsection{Phenotypic Antimicrobial Resistance Tests}

Antimicrobials were selected for testing based on the licensing for mastitis treatment in cattle, use in human medicine and potential resistant determinant phenotypes [19] [20]. Susceptibility of the isolates were determined against 10 antimicrobial agents as commercial discs (Oxoid) which commonly used for treatment of bovine mastitis in Egypt or considered as important agents for humans as follows: antimicrobials used for treatment of 
bovine mastitis included in this study were ciprofloxacin $(5 \mu \mathrm{g})$, erythromycin $(15 \mu \mathrm{g})$, gentamicin $(10 \mu \mathrm{g})$, penicillin (10 units) and tetracycline (30 $\mu \mathrm{g})$. Antimicrobials not used for treatment of bovine mastitis but important for humans were clindamycin $(2 \mu \mathrm{g})$, oxacillin $(1 \mu \mathrm{g})$, rifampicin $(5 \mu \mathrm{g})$ and vancomycin $(30 \mu \mathrm{g})$. Isolates were inoculated into Mueller-Hinton broth (Oxoid) and incubated overnight at $37^{\circ} \mathrm{C}$. The turbidity of the suspensions were adjusted to a 0.5 McFarland standard and streaked onto Mueller-Hinton agar (Oxoid) plates. Antimicrobial disks were added on the plates and they were incubated aerobically at $35^{\circ} \mathrm{C}$ for $16-18 \mathrm{~h}$. The results were recorded as susceptible, intermediate, or resistant by measurement of the inhibition zone diameter. Resistance was determined by measurement of inhibition of growth around the antimicrobial disk according to the zone diameter interpretative standards of CLSI [21] or according to the antimicrobials manufacturers' instructions. The reference strain S. aureus ATCC 25923 was used as the quality control organism and included with each batch of isolates tested.

\subsection{Molecular Detection of Coagulase (coa) Gene and Methicillin Resistance Genes (mecA) Gene in Staphylococcal Isolates}

\subsubsection{DNA Extraction}

Prior to DNA extraction, the bacterial strains were cultivated on blood agar base (Oxoid, Germany) containing 5\% defibrinated sheep blood for $24 \mathrm{~h}$ at $37^{\circ} \mathrm{C}$ then genomic DNA of randomly selected 60 staphylococci strains were extracted by using an extraction kit (QIA amp mini kit, Qiagen). DNA was stored at $-20^{\circ} \mathrm{C}$. To detect coa gene and mecA gene in examined staphylococcal isolates, specific oligonucleotide primers for coa gene and mecA gene were described in Table 1. All primers were supplied by Sigma Genosys (Sigma).

\subsubsection{PCR for Detection of coa Gene Specific for Coagulase Production}

The reaction with these primers were carried out using a total volume of $25 \mu 1$ reaction mixtures contained $5 \mu 1$ of DNA as template, 20 pmol of each primer and 1× of PCR master mix (Dream Taq Green PCR Master Mix, Fermentas Life Science). Amplification was conducted in Thermal cycler which was adjusted for detection of coa gene as follows, an initial denaturation at $94^{\circ} \mathrm{C}$ for $45 \mathrm{sec}$. The cycling proceeded for 30 cycles of denaturation at $94^{\circ} \mathrm{C}$ for $20 \mathrm{sec}$, annealing at $57^{\circ} \mathrm{C}$ for $15 \mathrm{sec}$, and extension at $70^{\circ} \mathrm{C}$ for $15 \mathrm{sec}$ with a final step of final extension at $72^{\circ} \mathrm{C}$ for $2 \mathrm{~min}$.

\subsubsection{PCR for Detection of mecA Gene Specific for Methicillin Resistance}

The reaction with these primers were carried out using a total volume of $25 \mu 1$ reaction mixtures contained $5 \mu \mathrm{l}$ of DNA as template, 20 pmol of each primer and 1× of PCR master mix (Dream Taq Green PCR Master Mix, Fermentas Life Science). Amplification was conducted in Thermal cycler which was adjusted for detection of mecA gene as follows, an initial denaturation at $94^{\circ} \mathrm{C}$ for $4 \mathrm{~min}$. The cycling proceeded for 35 cycles of denaturation at $94^{\circ} \mathrm{C}$ for $60 \mathrm{sec}$, annealing at $55^{\circ} \mathrm{C}$ for $60 \mathrm{sec}$, and extension at $72^{\circ} \mathrm{C}$ for $60 \mathrm{sec}$ with a final step of final extension at $72^{\circ} \mathrm{C}$ for $10 \mathrm{~min}$.

\section{Results}

\subsection{Isolates}

All suspected colonies were examined under light microscope to detect Gram positive cocci occurring singly, in pairs, in short chain or in irregular clusters like bunch of grapes. The results of traditional biochemical tests and

Table 1. Primer sequences for coa gene specific for coagulase production and mecA gene specific for methicillin resistance in staphylocooci.

\begin{tabular}{cccc}
$\begin{array}{c}\text { Primers } \\
\text { target }\end{array}$ & Sequence & Anneali-ng & $\begin{array}{c}\text { Amplified } \\
\text { product size }\end{array}$ \\
\hline$($ coa $)$ & $\begin{array}{c}\text { ATA GAG ATGCTG GTA CAG G } \\
\text { GCT TCC GATTGT TCG ATG C }\end{array}$ & $57^{\circ} \mathrm{C}$ & $750 \mathrm{bp}$ \\
$(m e c A)$ & $\begin{array}{l}\text { GTGAAGATATACCAAGTGATT3' } \\
\text { ATGCGCTATAGATTGAAAGGAT3 }\end{array}$ & $55^{\circ} \mathrm{C}$ & $147 \mathrm{bp}$ \\
\hline
\end{tabular}


API-Staph Kits indicated that all isolates are Staphylococci spp. A total of 200 staphylococci strains were isolated with percentage $66.7 \%$ (200/300).

\subsection{Investigation of Coagulase Production by Coagulase Tube Test}

The total of S. aureus strains are 70 with percentage 35\% (70/200). Among 70 strains of S. aureus, 30 strains are coagulase positive S. aureus with percentage $43 \%$ (30/70) and coagulase negative $S$. aureus 57\% (40/70). CNS other than S. aureus was detected with percentage 65\% (130/200) from subclinical mastitic cows. The previous results were illustrated in Table 2 and Table 3.

\subsection{Detection of coa Gene Specific for Coagulase Enzyme Production}

Sixty staphylococci strains were randomly selected for detection of coa gene, our results showed somewhat differences between phenotypic and genotypic detection of coagulase enzyme. It was noted that 10 strain of $S$. $a u$ reus, classified as coagulase negative by tube coagulase test were found to be positive with PCR. This result was illustrated in Table 4.

\subsection{Detection of mecA Gene Specific for Methicillin Resistance}

The results of PCR for amplification of $147 \mathrm{bp}$ fragment for mecA gene performed with its specific primer were observed in Table 5.

Table 2. Number and percentage of CPS and CNS strains differentiated according to coagulase test and API kit.

\begin{tabular}{cccccc}
\hline $\begin{array}{c}\text { No. of } \\
\text { samples }\end{array}$ & $\begin{array}{c}\text { Staphylococci } \\
\text { strains }\end{array}$ & $\begin{array}{c}\text { S. aureus } \\
\text { strains }\end{array}$ & CP S. aureus & CN S. aureus & CNS other than S. aureus \\
\hline 300 & $200(66.7 \%)$ & $70(35 \%)$ & $30(43 \%)$ & $40(57 \%)$ & $130(65 \%)$ \\
\hline
\end{tabular}

Table 3. Classification of CNS other than S. aureus according to API kit results.

\begin{tabular}{lcc}
\hline No. of CNS other than S. aureus & CNS other than S. aureus & No \% \\
\hline & S. chromogenes & $40(31 \%)$ \\
& S. simulans & $10(7.7 \%)$ \\
& S. haemolyticus & $30(23 \%)$ \\
& S. epidermidis & $35(27 \%)$ \\
\hline
\end{tabular}

Table 4. Phenotypic and genotypic differences in detection of coagulase enzyme.

\begin{tabular}{|c|c|c|c|c|c|c|}
\hline \multirow[b]{2}{*}{ Strains } & \multicolumn{2}{|c|}{ CP S. aureus (10 strains) } & \multicolumn{2}{|c|}{ CN S. aureus (10 strains) } & \multicolumn{2}{|c|}{$\begin{array}{c}\text { CNS other than S. aureus } \\
\text { (40 strains) }\end{array}$} \\
\hline & $\begin{array}{c}\text { Number of } \\
\text { positive strains }\end{array}$ & $\%$ & $\begin{array}{l}\text { Number of positive } \\
\text { strains }\end{array}$ & $\%$ & $\begin{array}{c}\text { Number of positive } \\
\text { strains }\end{array}$ & $\%$ \\
\hline $\begin{array}{c}\text { Phenotypic } \\
\text { (coagulase test) }\end{array}$ & 10 & 100 & 0 & 0 & 0 & 0 \\
\hline Genotypic (coa gene) & 10 & 100 & 10 & 100 & 0 & 0 \\
\hline
\end{tabular}

Table 5. Results of PCR for amplification detection of $147 \mathrm{bp}$ fragment for mecA gene performed with their specific primer.

\begin{tabular}{cccccc}
\hline Gene & CP S. aureus (10) & CN S. aureus (10) & CNS other than S. aureus (40) \\
$\begin{array}{c}\text { positive } \\
\text { of mecA gene }\end{array}$ & $\%$ & $\begin{array}{c}\text { positive } \\
\text { amplification } \\
\text { of mecA gene }\end{array}$ & $\%$ & $\begin{array}{c}\text { positive } \\
\text { amplification of } \\
\text { mecA gene }\end{array}$ \\
\hline mecA & 2 & $20 \%$ & 1 & $10 \%$ & 9 \\
\hline
\end{tabular}




\section{Discussion}

Mastitis is one of the major causes in financial losses for dairy cattle farmers. Staphylococcal species associated with bovine mastitis have been classified as coagulase positive or coagulase negative. CNS has become the most common bovine mastitis isolate in many countries and could therefore be described as emerging mastitis pathogens. CNS is not as pathogenic as the other principal mastitis pathogens and infection mostly remains subclinical. However, CNS can cause persistent infections, which result in increased milk somatic cell count (SCC) and decreased milk quality [24]. The current results reported that CNS was the predominant isolate recovered from subclinical mastitis cows with percentage 65\%, these result was in harmony with El-Jakee et al. [25] who reported that CNS is generally high in subclinical mastitic samples, but low in samples from animals with clinical mastitis.

In our study, S. chromogenes, S. epidermidis and S. haemolyticus were the most prevalent CNS with percentage $31 \%, 27 \%$ and $23 \%$ respectively.

Our results were nearly agreed with Waller et al. [26] who reported that S. epidermidis was the most common CNS in Subclinical mastitis and S. haemolyticus was also quite common, Piessens et al. [4] stated that S. chromogenes and S. haemolyticus to be the most common species in milk samples from cows with intramammary infections (IMI). Persistent IMI was common to quarters infected with S. epidermidis indicating a more udderadapted origin [27].

Molecular typing of microorganisms is very essential for infection control programs. These molecular techniques are rapid and accurate. On the other side, traditional phenotypic methods have several drawbacks.

Recent studies recommended that phenotypic and genotypic identification of CNS do not necessarily agree [28].

According to our results, we found that10 strains, classified as coagulase negative by tube coagulase test were found to be positive with PCR, this result was completely agreed with Gharib et al. [29] who mentioned that 2 strains, classified as coagulase negative by tube coagulase test were found to be positive with PCR amplification of the gene which clearly emphasizes the use of molecular methods in detecting S. aureus. The coa gene amplification has been considered a simple and accurate method for typing of $S$. aureus isolated from distinct sources, the coagulase protein is an important virulence factor of S. aureus. Like spa, coa has a polymorphic repeat region that can be used for differentiating $S$. aureus isolates. The variable region of coa gene is comprised of 81 bp tandem short sequence repeats (SSRs) [30].

In our study, all PCR products for coa gene were detected at $750 \mathrm{bp}$, this result agreed with Schlegelova et al. [31] who reported the size of coa gene PCR product of S. aureus isolates from dairy cow and human are 650 1050 bp.

Emerging antimicrobial resistance among CNS is a concern in veterinary and human medicine. Archer and Climo [32] reported an escalation of resistance for almost all antimicrobial classes excluding glycopeptides: $\beta$ lactams aminoglycosides, trimethoprim, rifampin, fluoroquinolones, macrolides, and tetracyclines. Humans and dairy cattle may share CNS strains, implying that bovine multidrug resistant staphylococci might be zoonotic pathogens [33].

The widespread use of antibiotics on dairy farms and other food-producing animals could lead to the selection and emergence of antibiotic resistant bacterial strains [34] to become a serious public health problem because of the possibility of dissemination of the antimicrobial resistant bacteria to humans via food. In Egypt, very little is known about the use of antibiotics on small dairy farms as is the case in lower/middle-income countries. Redding et al. [35] found that the farmers' knowledge of antibiotics was significantly associated with the use of antibiotics for preventative reasons, the purchase of antibiotics from feed-stores, the experience of complications in animals after having administered antibiotics, the number of workers on the farm, the educational level of the farmer and its infrequent use, because therapeutic interventions were sought only when the animal had reached an advanced stage of clinical disease. Also, because of their inability to define an antibiotic and in contrast to Redding et al. [35], many farmers do not understand that the use of antibiotics carried inherent risks to their animals and potentially to the consumers of dairy products from treated animals. In the recent study to Osman et $a l$. [9], the highest resistance rate was observed against penicillin, ampicillin and oxacillin in CNS isolates. The emergence of high levels of penicillin resistance followed by the development and spread of strains resistant to the semisynthetic penicillin (oxacillin), macrolides, tetracyclines, and aminoglycosides has made the therapy of staphylococcal disease a global challenge [33]. In the present work, mecA gene was detected with high incidence 
in CNS other than S. aureus followed by CP S. aureus and CN S. aureus with percentage $22 \%, 20 \%$ and $10 \%$ respectively. Our result supported by Bochniarz et al. [36] who reported that, recently a significant increase has been observed in the number of isolated methicillin resistance CNS (mecA-gene-positive) which are resistant to all groups of $\beta$-lactam antibiotics. Taponen and Pyorala [37] stated that, mastitis-causing coagulase-negative staphylococci (CNS) tend to be more resistant to antimicrobials than $S$. aureus and may be a source of $\beta$-lactam resistance genes.

The importance of CNS has increased and they have become the predominant pathogens isolated from subclinical mastitis in several countries which leading to economic losses resulting in decreased milk production. In addition to that, studying antimicrobial susceptibility of CNS at the species level can provide valuable information about species-specific differences that can be vital data for effective mastitis therapy and control [33]. The significance of our study in the prevention of staphylococci contamination in milk is to avoid spread of resistant strains of staphylococci from animal to anther and to human.

\section{Conclusion}

Because of the possibility of misidentifying S. aureus as CNS depending on coagulase test only so we recommend that genotypic detection to coa gene is very important for identification as well as the possibility of dissemination of the antimicrobial resistant bacteria to humans via the food processing chains. Screening the dairy industry for antimicrobial resistant bacteria should be performed as the resistance genes might in some instances transfer from staphylococci of animal origin to staphylococci that cause infections in humans, thereby compromising antimicrobial treatment.

\section{References}

[1] Cheng, A.G., Mcadow, M., Kim, H.K., Bae, T., Missiakas, D.M. and Schneewind, O. (2010) Contribution of Coagulases towards Staphylococcus aureus Disease and Protective Immunity. PLoS Pathogens, 6, 1-17. http://dx.doi.org/10.1371/journal.ppat.1001036

[2] Koneman, E.W., Allen, S.D., Janda, W.M., Schreckenberger, P.C. and Winn, W.C. (1992) Gram-Positive Coccipart I: Staphylococci and Related Organisms. In: Color Atlas and Textbook of Diagnostic Microbiology, JP Lippincott Company, Philadelphia, 405-429.

[3] Ajitkumar, P., Barkema, H.W., Zadoks, R.N., Morck, D.W., van der Meer, F.J.U.M. and De Buck, J. (2013) High Resolution Melt Analysis for Species Identification of Coagulase-Negative Staphylococci Derived from Bovine Milk. Diagnostic Microbiology and Infectious Disease, 75, 227-234. http://dx.doi.org/10.1016/j.diagmicrobio.2012.11.008

[4] Piessens, V., Van Coillie, E., Verbist, B., Supré, K., Braem, G., Van Nuffel, A., De Vuyst, L., Heyndrickx, M. and De Vliegher, S. (2011) Distribution of Coagulase-Negative Staphylococcus Species from Milk and Environment of Dairy Cows Differs between Herds. Journal of Dairy Science, 94, 2933-2944. http://dx.doi.org/10.3168/jds.2010-3956

[5] Braem, G., De Vliegher, S., Verbist, B., Piessens, V., Van Coillie, E., De Vuyst, L. and Leroy, F. (2013) Unraveling the Microbiota of Teat Apices of Clinically Healthy Lactating Dairy Cows, with Special Emphasis on CoagulaseNegative Staphylococci. Journal of Dairy Science, 96, 1499-1510. http://dx.doi.org/10.3168/jds.2012-5493

[6] Osman, K.M., Abd El-Razik, K.A., Marie, H.S.H. and Arafa, A.A. (2015) Relevance of Biofilm Formation and Virulence of Different Species of Coagulase-Negative Staphylococci to Public Health. European Journal of Clinical Microbiology \& Infectious Diseases, 34, 2009-2016. http://dx.doi.org/10.1007/s10096-015-2445-3

[7] Ender, M., Mccalum, N., Adhikari, R. and Berger-Bachi, B. (2004) Fitness Cost of SCCmec and Methicillin Resistance Levels in Staphylococcus aureus. Antimicrobial Agents and Chemotherapy, 48, 2295-2297. http://dx.doi.org/10.1128/AAC.48.6.2295-2297.2004

[8] Cosgrove, S.E., Sakoulas, G., Perencevich, E.N., Schwaber, M.J., Karchmer, A.W. and Carmeli, Y. (2003) Comparison of Mortality Associated with Methicillin-Resistant and Methicillin-Susceptible Staphylococcus aureus Bacteremia: A Meta-Analysis. Clinical Infectious Diseases, 36, 53-59. http://dx.doi.org/10.1086/345476

[9] Osman, K.M., Abd El-Razik, K.A., Marie, H.S.H. and Arafa, A.A. (2015) Coagulase-Negative Staphylococci Collected from Bovine Milk: Species and Antimicrobial Genes Diversity. Journal of Food Safety, Article First Published Online: 16 AUG 2015. http://dx.doi.org/10.1111/jfs.12216

[10] Irlinger, F. (2008) Safety Assessment of Dairy Microorganisms: Coagulase-Negative Staphylococci. International Journal of Food Microbiology, 126, 302-310. http://dx.doi.org/10.1016/j.ijfoodmicro.2007.08.016

[11] Vitali, L.A., Petrelli, D., Lamikanra, A., Prenna, M. and Akinkunmi, E.O. (2014) Diversity of Antibiotic Resistance Genes and Staphylococcal Cassette Chromosome mec Elements in Faecal Isolates of Coagulase-Negative Staphylo- 
cocci from Nigeria. BMC Microbiology, 14, 106. http://dx.doi.org/10.1186/1471-2180-14-106

[12] Hisata, K., Ito, T., Matsunaga, N., et al. (2011) Dissemination of Multiple MRSA Clones among Community-Associated Methicillin-Resistant Staphylococcus aureus Infections from Japanese Children with Impetigo. Journal of Infection and Chemotherapy, 17, 609-621. http://dx.doi.org/10.1007/s10156-011-0223-4

[13] Schnellmann, C., Gerber, V., Rossano, A., Jaquier, V., Panchaud, Y., Doherr, M.G., Thomann, A., Straub, R. and Perreten, V. (2006) Presence of New mecA and $m p h(C)$ Variants Conferring Antibiotic Resistance in Staphylococcus spp. Isolated from the Skin of Horses before and after Clinic Admission. Journal of Clinical Microbiology, 44, 4444-4454. http://dx.doi.org/10.1128/JCM.00868-06

[14] Soge, O.O., Meschke, J.S., No, D.B. and Roberts, M.C. (2009) Characterization of Methicillin-Resistant Staphylococcus aureus and Methicillin-Resistant Coagulase-Negative Staphylococcus spp. Isolated from US West Coast Public Marine Beaches. Journal of Antimicrobial Chemotherapy, 64, 1148-1155. http://dx.doi.org/10.1093/jac/dkp368

[15] Zhou, F. and Wang, Y. (2013) Characteristics of Antibiotic Resistance of Airborne Staphylococcus Isolated from Metro Stations. International Journal of Environmental Research and Public Health, 10, 2412-2426. http://dx.doi.org/10.3390/ijerph10062412

[16] Oliver, S.P., Gonzalez, R.N., Hogan, J.S., Jayarao, B.M. and Owens, W.E. (2004) Microbiological Procedures for the Diagnosis of Bovine Udder Infection and Determination of Milk Quality. Fourth Edition, National Mastitis Council, Madison.

[17] Quinn, P.J., Markey, B.K., Leonard, F.C., Fitz Patrick, E.S., Fanning, S. and Hartigan, P.J. (2011) Veterinary Microbiology and Microbial Diseases. Second Edition, Wiley-Blackwell, Chichester.

[18] Petzer, I.M., Karzis, J., Lesosky, M., Wayermeyer, J.C. and Badenhorst, R. (2013) Host Adapted Intramammary Infections in Pregnant Heifers Which Were Co-Housed and Reared on Fresh Milk as Calves. BMC Veterinary Research, 9, 49. http://dx.doi.org/10.1186/1746-6148-9-49

[19] FAO/WHO/OIE (2008) Report of the Joint FAO/WHO/OIE Expert Meeting on Critically Important Antimicrobials. Rome, 26-30 November 2007. FAO, Rome and WHO, Geneva.

[20] WHO, World Health Organization (2009) Critically Important Antimicrobials for Human Medicine. 2nd Revision, WHO Advisory Group on Integrated Surveillance of Antimicrobial Resistance (AGISAR), Department of Food Safety and Zoonoses.

[21] CLSI, Clinical and Laboratory Standards Institute (2012) Performance Standards for Antimicrobial Susceptibility Testing; Twenty-Second 154 Informational Supplement. M100-S22, Volume 32, No. 3, Replaces M100-S21, Volume 31, No.1.

[22] Hookey, J.V., Richardson, J. and Cookson, B.D. (1998) Molecular Typing of Staphylococcus aureus Based on PCR Restriction Fragment Length Polymorphism and DNA Sequence Analysis of the Coagulase Gene. Journal of Clinical Microbiology, 36, 1083-1089.

[23] Zhang, K., McClure, J.A., Elsayed, S.T., Louie, T. and Conly, J.M. (2005) Novel Multiplex PCR Assay for Characterization and Concomitant Subtyping of Taphylococcal Cassette Chromosome mec Types I to V in Methicillin-Resistant Staphylococcus aureus. Journal of Clinical Microbiology, 43, 5026-5033. http://dx.doi.org/10.1128/JCM.43.10.5026-5033.2005

[24] Pyörälä, S. and Taponen, S. (2009) Coagulase-Negative Staphylococci-Emerging Mastitis Pathogens. Veterinary Microbiology, 134, 3-8. http://dx.doi.org/10.1016/j.vetmic.2008.09.015

[25] El-Jakee, J.K., Aref, N.E., Gomaa, A., El-Hariri, M.D., Galal, H.M., Omar, S.A. and Samir, A. (2013) Emerging of Coagulase Negative Staphylococci as a Cause of Mastitis in Dairy Animals: An Environmental Hazard. International Journal of Veterinary Science and Medicine, 1, 74-78. http://dx.doi.org/10.1016/j.ijvsm.2013.05.006

[26] Waller, K.P., Aspan, A., Nyman, A., Persson, Y. and Andersson, U.G. (2011) CNS Species and Antimicrobial Resistance in Clinical and Subclinical Bovine Mastitis. Veterinary Microbiology, 152, 112-116. http://dx.doi.org/10.1016/j.vetmic.2011.04.006

[27] Thorberg, B.M., Kuhn, I., Aarestrup, F.M., Brändstrom, B., Jonsson, P. and Danielsson-Tham, M.L. (2006) Pheno- and Genotyping of Staphylococcus epidermidis Isolated from Bovine Milk and Human Skin. Veterinary Microbiology, 115, 163-172. http://dx.doi.org/10.1016/j.vetmic.2006.01.013

[28] Taponen, S., Simojoki, H., Haveri, M., Larsen, H.D. and Pyörälä, S. (2006) Clinical Characteristics and Persistence of Bovine Mastitis Caused by Different Species of Coagulase Negative Staphylococci Identified with API or AFLP. Veterinary Microbiology, 115, 199-207. http://dx.doi.org/10.1016/j.vetmic.2006.02.001

[29] Gharib, A.A., Adel Attia, M.A. and Bendary, M.A. (2013) Detection of the Coa Gene in Staphylococcus aureus from Different Sources by Polymerase Chain Reaction. International Journal of Microbiological Research, 4, 37-42.

[30] Van Belkum, A., Scherer, S., Van-Alphen, L. and Verbrugh, H. (1998) Short-Sequence DNA Repeats in Prokaryotic Genomes. Microbiology and Molecular Biology Reviews, 62, 275-293. 
[31] Schlegelova, J., Dendis, M., Benedik, J., Babak, V. and Rysanek, D. (2003) Staphylococcus aureus Isolates from Dairy Cow and Human on a Farm Differ in Coagulase Genotype. Veterinary Microbiology Journal, 92, 327-334. http://dx.doi.org/10.1016/S0378-1135(02)00409-1

[32] Archer, G.L. and Climo, M.W. (1994) Antimicrobial Susceptibility of Coagulase Negative Staphylococci. Antimicrobial Agents and Chemotherapy, 38, 2231-2237. http://dx.doi.org/10.1128/AAC.38.10.2231

[33] Soares, L.C., Pereira, I.A., Pribul, B.R., Oliva, M.S., Coelho, S.M.O. and Souza, M.M.S. (2012) Antimicrobial Resistance and Detection of mec and blaZ Genes in Coagulase-Negative Staphylococcus Isolated from Bovine Mastitis. Pesquisa Veterinária Brasileira, 32, 692-696. http://dx.doi.org/10.1590/S0100-736X2012000800002

[34] Oliver, S.P., Murinda, S.E. and Jayarao, B.M. (2011) Impact of Antibiotic Use in Adult Dairy Cows on Antimicrobial Resistance of Veterinary and Human Pathogens: A Comprehensive Review. Foodborne Pathogens and Disease, 8, 337-355. http://dx.doi.org/10.1089/fpd.2010.0730

[35] Redding, L.E., Cubas-Delgado, F., Sammel, M.D., Smith, G., Galligan, D.T., Levy, M.Z. and Hennessy, S. (2014) The Use of Antibiotics on Small Dairy Farms in Rural Peru. Preventive Veterinary Medicine, 113, 88-95. http://dx.doi.org/10.1016/j.prevetmed.2013.10.012

[36] Bochniarz, M., Wawron, W. and Szczubiał, M. (2013) Resistance to Methicillin of Coagulase-Negative Staphylococci (CNS) Isolated from Bovine Mastitis. Polish Journal of Veterinary Sciences, 16, 687-692. http://dx.doi.org/10.2478/pjvs-2013-0097

[37] Taponen, S. and Pyörälä, S. (2009) Coagulase-Negative Staphylococci as Cause of Bovine Mastitis—Not So Different from Staphylococcus aureus? Veterinary Microbiology, 134, 29-36. http://dx.doi.org/10.1016/j.vetmic.2008.09.011 